\title{
Interacción del mundo artístico y psicológico en Doña Luz de Juan Valera
}

GILBERT PAOLINI

Tulane University, New Orleans

En el mundo de la mitología hay una larga y compleja tradición dentro de la cual la creación humana no se efectúa por medio de la unión física sino mediante un fenómeno: un sueño, una visión, una mirada, etc. En el mundo de la literatura clásica, hay ejemplos por los que queda claro que una pintura o una escultura en que se fija la mirada de una mujer causa en la criatura por nacer una transformación que refleja la observada obra de arte. En la literatura moderna española, Valera, en Doña $L u z$, va más allá en la aceptación de los conceptos de creatividad ya indicados $y$, transponiendo ese poder creador exterior al mismo espíritu de doña Luz, hace que se verifique una metamorfosis en el feto $\mathrm{y}$, por consiguiente, el recién nacido, más que al padre natural, se asemeja al hombre a quien doña Luz ama. Bastante complejo es el proceso creador de Valera en Doña $L u z$, ya que halla su inspiración en el hondo conocimiento de la literatura antigua así como de la moderna, mientras bebe en la fuente de la superstición, flota entre las leyendas paganas y cristianas y se extasia en la contemplación del arte. Además, en Doña Luz evidenciamos una confluencia de actitudes, mitos y leyen- 
das procedentes del mundo oriental, que Valera diestramente funde en una ecléctica totalidad. Sin embargo, es este mismo eclecticismo lo que hace la novela en extremo sugestiva y fascinante, y, no obstante, evasiva.

Que el cambio pueda ocurrir en el feto en cada momento durante o después de la concepción es muy importante, y la creencia se pierde en la antigüedad. Un ejemplo excelente es la Historia Etiópica de Heliodoro. La historia novelesca se ciñe alrededor del destino de Cariclea, que nació blanca de padres etíopes. La epopeya de Cariclea empieza cuando su madre, Persina, le explica la circunstancia de su nacimiento. Casada más de diez años y sin haber podido tener hijos, Persina relata cómo una tarde de verano, echando la siesta en el dormitorio del Rey, donde las paredes ilustraban los amores de Perseo y Andrómeda, «vuestro padre [...] se ayuntó conmigo, y luego me sentí preñada [...] Mas cuando os parí blanca y tan hermosa, que es una color no acostumbrada a los de Etiopía, yo cierto bien conocí la causa, que era porque tuve los ojos, cuando vuestro padre se ayuntó conmigo, en la figura de Andrómeda, desnuda como estuvo cuando Perseo la sacaba de la roca, que fue causa que vos fuistes [...] concebida blanca y tan semejante a ella» ${ }^{1}$.

López Pinciano, para explicar, en Filosofía antigua poética, los poderes creativos y reproductivos de la imaginación, se sirve del caso de Cariclea relatado por Heliodoro y añade:

El caso de la reina de Etiopía no es imposible, que là imaginación al tiempo de la generación llevase algún humor blanco y rubio a las partes della, y engendrase alba criatura la madre negra ${ }^{2}$.

El escritor árabe Ibn Hazm de Córdoba, en su obra El collar de la paloma, escribe:

Se cuenta asimismo de un fỉsiognomista experto que le trajeron un niño negro nacido de dos padres blancos. Después de haber examinado todos sus rasgos, comprobó que era de ambos, sin duda alguna, y entonces pidió que le llevaran al sitio en que habian cohabitado los padres. Al entrar en la habitación en que estaba el lecho, vio la imagen de un negro en la parte del muro donde recaía la mirada de la mujer. "Por culpa de esta imagen —dijo al padre- has tenido este hijo", 3 .

1 Heliodoro, Historia etiópica de los amores de Teágenes y Cariclea, editada por Francisco López Estrada, Madrid, Aldus, 1954, pp. 153-54.

2 Alonso López Pinciano, Filosofía antigua poética, Valladolid, Hijos de Rodríguez, 1894, p. 29.

3 Ibn Hazm de Córdoba, El collar de la paloma, traducción de Emilio García Gómez, Madrid, Sociedad de Estudios y Publicaciones, 1952, p. 81. 
El poeta italiano Torquato Tasso, en la Gerusalemme liberata (1580), se inspira en la artística tradición pagana, y crea, bajo distintos conceptos de verdad y belleza, a Clorinda, la versión cristiana de Cariclea. Clorinda, una joven extraordinariamente bella, había nacido blanca de padres etíopes. Se debió esto a que su madre, otra reina de Etiopía, detenida en la alcoba por el celoso marido, pasaba mucho tiempo llorando delante del cuadro que representaba la leyenda de San Jorge matando el dragón para libertar a la blanca doncella ${ }^{4}$.

Los dos escritores, Heliodoro, pagano, y Tasso, cristiano, han basado su creación poética sobre el efecto que la imaginación, estimulada por una representación artística, ha causado en el fruto de la procreación.

A través de los siglos se ha dado gran importancia al arte mismo como medio de mejorar la condición humana. En Grecia, en el siglo $\mathrm{V}$ antes de Jesucristo, se creía que el fin del arte era crear formas perfectas de hombres y dioses ${ }^{5}$. También se creía que «las más altas aspiraciones del espíritu podrían expresarse en la perfección de la forma humana basada en la armonía y en la perfección ${ }^{6}$. En la segunda mitad del siglo $\mathrm{V}$ antes de Jesucristo, «se creyó haber alcanzado la armonía perfecta de la forma ideal y la naturaleza en su representación de la figura humana» ${ }^{\text {. }}$.

Tal concepto y actitud hacia la función del arte también la encontramos en el Renacimiento y, entre otros, en el filósofo y escritor italiano Tommaso Campanella, cuando explica en su obra Civitas solis (1623), cómo se pueden engendrar ciudadanos perfectos ${ }^{8}$.

También es interesante poner de manifiesto la actitud de Valera mismo hacia la función sociológica del arte. En «Teatro libre», al dar la definición del tipo de artista que desearía ver en la formación de la compañía de actores para el nuevo teatro de Madrid con que sueña, Valera inequívocamente insiste en lo esencial de la hermosura de los actores y especialmente de las actrices. Explica: «La educación estética de un pueblo no se forma ni se mejora, sino se corrompe y se vicia, manifestándole lo feo, lo inelegante [...], lo estropeado, lo ruin y lo plebeyo

4 Torquato Tasso, Gerusalemme Liberata, Milano, Carlo Signorelli, 1946, Canto XII, pp. 23-24.

5 Donald E. Strong, The Classical World, New York, McGraw-Hill, 1965, p. 9.

6 Strong, p. 9.

7 Ibid.

8 Tommaso Campanella, La città del sole, Roma, Colombo Editore, 1953, p. 64. 
de la figura humana» ${ }^{9}$. Apoyándose en su conocimiento de la cultura griega, añade:

Así como la naturaleza influye en el arte, ya que Fidias y Praxiteles no hubieran esculpido las maravillosas imágenes de Júpiter, Minerva y Venus si no hubieran tenido modelos de gran valor, así el arte influye en la naturaleza, porque las mujeres y los hombres que contemplan lo bello en las representaciones artísticas, se enriquecen la imaginación, e influyendo esto en todo el organismo vital, hace que nazcan chiquillas y chiquillos preciosos ${ }^{10}$.

Valera, refiriéndose específicamente al siglo $\mathrm{V}$ antes de Jesucristo, concluye:

Está probado que, desde el siglo de Pericles en adelante, las mujeres griegas, a fuerza de contemplar las obras maestras de la escultura y de la pintura, vinieron a ser mucho más hermosas que en los siglos anteriores ".

En otras ocasiones, Valera constantemente manifiesta su creencia en el poder del arte sobre el ser humano, y en su correspondencia comenta cómo, durante su visita a Roma, había notado la fuerte semejanza entre las mujeres romanas y las estatuas de la antigüedad, y explica que, «debido a la contemplación de dichas bellas estatuas, la mujer romana había ido perfeccionándose de líneas al paso de los tiempos» ${ }^{12}$.

En Doña Luz (1879), Valera, mientras introduce unas variantes que muestran su propia originalidad, ha creado entre los personajes principales, el Padre Enrique y doña Luz, una situación que se parece y corre paralela a la leyenda de Perseo y Andrómeda y la de San Jorge y la doncella. Lo malo de antaño, identificado con el mítico monstruo marino contra Andrómeda, con la bíblica serpiente contra Eva, con el legendario dragón contra la joven cristiana, se ha metamorfoseado adaptándose al ambiente moral, social, político y literario de la época moderna. Como ejemplo, citemos a Belfagor en Maquiavelo, a Mefistófeles en Goethe, al Caballero de negro en Casona y a la locomotora en la psicología moderna.

Valera moderniza y funde las dos leyendas de Perseo y San Jorge, mientras les añade elementos provenientes de otras sagas. Crea un mito que, con un ambiente todo suyo, es aceptable y creíble en la España decimonónica. La bella tradición de la antigụedad pagana, que había ser-

9 Juan Valera, «Teatro libre», en Crítica literaria, 1889-1896, Obras Completas, XXVIII, Madrid, 1911, p. 322.

10

Ibid.

11 Ibíd.

12 Manuel Bermejo Marcos, Don Juan Valera, crítico literario, Madrid, Editorial Gredos, 1968, p. 65. 
vido de inspiración al mundo cristiano y luego se había prestado a otra interpretación entre los autores del Renacimiento, se renueva por medio de la facultad del cristianismo pagano de Valera, que capturó todos los elementos armónicos, los combinó en un hermoso rito dentro del cual insufló el alma consciente de su fuerza psicológica.

En este nuevo mito, doña Luz es la Andrómeda/doncella que, en momentos de apuro, se viste de la armadura-héroe/Perseo/San Jorge de la voluntad y, en combate singular, vence al monstruo, su esposo, don Jaime Pimentel. Derrotado «el enemigo», goza de los frutos de la victoria. Doña Luz, mediante su fuerte voluntad, rechaza a su compañero físico, a su marido, como padre del niño aún no nacido y causa en el niño la reencarnación del Padre Enrique, su amor espiritual. Doña Luz, después de hacer sentir a su buena amiga doña Manolita el niño aún no nacido que se mueve en su seno, exclama:

Yo viviré por él y para él. No quiero creer que una material impresión haya dejado aquí la imagen del hombre que desprecio. Mi espíritu concibe este ser. Mi pensamiento y mi voluntad, durante largos meses, le han prestado y le prestarán forma y le han dado y le darán alma semejante a la de aquel que me la dio toda. En los besos que estampé en su noble rostro, cuando moría, hubo más verdadero amor que en todos los abrazos que al otro prodigué alucinada ${ }^{13}$.

Todavía hay otra dimensión en la creación de este nuevo mito. Además de los elementos provenientes del mundo pagano y cristiano, encontramos en Doña Luz una confluencia de actitudes, de mitos y leyendas del mundo oriental, los cuales muy diestramente Valera funde en una ecléctica totalidad. Sin embargo, es este mismo eclecticismo lo que, como decíamos antes, hace la novela en extremo sugestiva y fascinante, y, no obstante, evasiva. A pesar de que Valera describa con muchos detalles la hermosura de doña Luz, sin embargo su belleza espiritual trasciende la física. Doña Luz está dotada de cierta calidad ennoblecedora y aparece superior a todos los que la rodean. Los personajes de la novela, lo mismo que el lector, la perciben sobre un pedestal y casi etérea, como Dante percibió a Beatriz. Más que en lo físico, su importancia radica en su manera de ser y en su pensamiento.

En muchas de las leyendas anteriormente mencionadas es evidente el efecto fascinante y la influencia de las pinturas sobre el ser humano. Igualmente, en esta novela doña Luz pasa diariamente horas ascéticamente extasiada ante el espantoso y: bello cuadro del Cristo muerto, atribuido al divino Morales:

13 Juan Valera, Doña Luz, Obras escogidas, Madrid, Biblioteca Nueva, s. a., II, p. 253. Las citas de esta obra se harán en adelante en el texto, entre parénteșis. 
Era la figura de Cristo, de medio cuerpo [...] Las barbas y los cabellos se podían contar. La regularidad y noble simetría de todas las facciones infundían amor y respeto; pero las angustias del patíbulo, los horrores de la agonía, los tormentos todos estaban marcados en aquella cara flaca, macilenta, y en aquel pecho y en aquel costado herido por la lanza. Era un Cristo muerto... (pág. 50)

Doña Luz halla extraño deleite en la detenida contemplación de este cuadro del Cristo muerto, y un día, mientras miraba la imagen, «se le antojó que se parecía al Padre Enrique» (pág. 163).

Al principio de la novela, cuando el Padre Enrique, el conquistador de las almas, regresa a Villafría, se revela como una persona excepcional que se pasa, en la soledad de su cuarto, horas y horas leyendo y escribiendo.

Mediante los discursos y diálogos intelectuales que tienen lugar en las tertulias diarias, las almas gemelas de doña Luz y el Padre Enrique se identifican y se establece entre ellas una relación espiritual: «como un alma ama a otra alma, cuando ambas coinciden en las mismas creencias y opiniones, suben a las mismas alturas y especulan y contemplan las mismas ideas» (pág. 100).

Es el Padre Enrique, misionero más de 20 años en la India y el Oriente quien, con su presencia, injerta en la novela los elementos mitológicos orientales. Esta larga contigüidad con el ambiente mítico oriental nos parece percibirla en el aura que le rodea. Esa súbita vuelta, como en exilio, ese extremado deseo de soledad, de estudio y meditación, se parece mucho a la situación del dios hindú Siva, a quien de una vida ascética distrae la rubia diosa Sati, también conocida bajo el otro nombre de Uma, que es personificación de la Luz y de la Belleza ${ }^{14}$. Siva es una divinidad extraordinariamente compleja. Es, a la vez, dio del ascetismo y de la sexualidad. Es la segunda divinidad en la tríada hindú de Brahma, Siva y Visnú. Busca las verdades eternas y no hace caso de los efímeros aspectos de la vida material. La meditación y la austeridad fortalecen su poder espiritual, dándole facultades ilimitadas para hacer milagros, como también su poder fecundador. Por eso hay que atribuir mucha importancia al regalo que el Padre Enrique hace a los novios, es decir, el extraño ídolo de bronce que representa al dios Siva. El regalo no es por mera casualidad, sino que el Padre Enrique lo escoge cuidadosamente entre los varios objetos que ha traído del Oriente.

De suma significación son los detalles del ataque apoplético y la

14 Veronica Ions, Indian Mythology, London, Paul Hamlyn, 1963, pp. 91-92. 
eventual muerte del Padre Enrique unos días después de la boda. El Padre Enrique se acuesta en el mismo cuarto que doña Luz «había ocupado hasta que se casó, y donde había dormido durante más de doce años» (pág. 211). En este mismo cuarto se cumple la unión espiritual. Doña Luz, mirando con fijeza al Padre Enrique, cree como nunca que aquel hombre se asemeja al Cristo muerto del cuadro, al Cristo muerto con quien todos los días había hablado y'a quien había besado en los labios. Doña Luz está convencida de que la extática mirada del agonizante Padre Enrique le suplica triste y amorosamente. Por un impulso irresistible, doña Luz «acercó suavemente el rostro al del padre y puso los labios en su frente macilenta, y luego en su boca, ya contraída, y los besó con devoción fervorosa como quien besa reliquias» (pág. 214). Este es el momento sublime, el momento de la compenetración espiritual. Doña Luz, recibiendo así el último suspiro y como en un acto de unión mística y éxtasis, «exhaló un jay! agudo y cayó desmayada en el suelo» (pág. 214). Se ha cumplido la sagrada unión arquetípica de dos almas, la unión espiritual de los elementos contrarios. En Siva, el destructor, también dios de la fecundidad, todos los elementos contrarios se reconcilian ${ }^{15}$.

Don Jaime, que mendosamente consiguió casarse con doña Luz, hizo el papel de esposo solamente para el injerto físico de la vida, ya que, descubierto el engaño, doña Luz lo rechaza rápida y terminantemente.

En el nacimiento de Cariclea en Heliodoro y de Clorinda en Tasso y en el comentario aclaratorio de Pinciano no se estableció ninguna relación directa entre la unión física y su fruto. En cada situación fue un caso de voluntad. De la misma manera, en esta novela es la fuerza de la voluntad lo que se impone y causa un desplazamiento y sustitución de genes. Hay yuxtaposición de dos efigies del Padre Enrique: 1) el cuadro de Cristo muerto en la habitación nupcial, el cual, en la mente de doña Luz, se parece al Padre Enrique, y 2) el rostro del moribundo Padre Enrique, que se parece al cuadro. Esta constante imagen, mediante la voluntad de doña Luz, causa una metamorfosis en la vida ya presente en su seno y adquiere otra vida. Es decir, el Padre Enrique en su muerte vuelve a nacer como Enrique, el hermoso e inteligente niño de doña Luz. Doña Luz explica cómo su voluntad ejecuta la sustitución genética.

15 R. C. Zaehner, «Hinduism» en Man, Myth and Magic, New York, Marshall Cavendish Corporation, 1970, X, p. 1314. 
Mi pensamiento y mi voluntad, durante largos meses, le han prestado y le prestarán forma y le han dado y le darán alma semejante a la de aquel que me la dio toda (pág 253).

Es esencial hacer notar otra vez que Valera llama a la protagonista doña Luz, y la describe rubia, con los ojos azules y personificación de la pulcritud y beldad (págs. 18-19). En la mitología hindú, la esposa del dios Siva, Sati, Parvati o Uma, es también la personificación de la Luz y de la Belleza. Además, en la teología hindú, con Sati se identifica la divina fuerza creadora:

And so it is said that Shiva begets Shakti and Shakti gives birth to Shiva... Still Shiva is ever chaste and the sweet speeched Shakti remains ever virgin. Only sages can comprehend this secret ${ }^{16}$.

La constante en la actitud de Heliodoro, Campanella, Tasso y Valera es que la contemplación de una obra de arte, sea una pintura o escultura, puede incitar y animar la mente del ser humano a imaginar, a desear. El inconsciente de la mujer se inspira en esta materia arquetípica y modificándola la moldea de conformidad con su deseo. La mente consciente, para poder satisfacer su deseo, necesita absolutamente el efecto en el inconsciente de la belleza o imagen objetivada en la obra de arte. Sin embargo, ya que cada deseo, ambición o sueño es particular para el individuo que lo experimenta, la forma exacta de la voluntad será determinada por la situación de cada individuo.

En doña Luz es esencial tener presentes los obstáculos que causan el voto de castidad y la subsecuente muerte del Padre Enrique, como también el hecho de que doña Luz sólo después de la muerte del Padre Enrique se dé cuenta del amor de él. Por consiguiente, doña Luz no busca la felicidad en el matrimonio, sino la continuación, la regeneración del Padre Enrique. El amor subconsciente de doña Luz por el Padre Enrique, viviente por la fuerza de la voluntad, se transmite en la forma física, en la esencia misma del niño que llevaba en su seno. El amor espiritual que subconscientemente ardía en la casta mente de doña Luz quiso objetivarse y exteriorizarse en el niño, Enrique.

En conclusión, podemos volver a afirmar que el proceso creador de Valera en Doña Luz es complejo, ya que halla su inspiración en la superstición, en las leyendas paganas y cristianas, en las religiones orientales, en el arte y en las literaturas antiguas y modernas. Todos estos elementos surgen a la vida evocados por su fuerza creadora, que 
refleja no solamente sus hondos conocimientos, sino también su actitud cristiana/pagana que tanto admiramos y tan a menudo encontramos en sus obras. 